\title{
FISTULA ARTERIOVENOSUS FASIALIS PADA KEHAMILAN
}

\author{
FACIAL ARTERIOVENOSUS FISTULA IN PREGNANCY
}

Risky Ilona Saputra, * Kumara Tini*

\begin{abstract}
Arteriovenosus fistula (AVF) of superficial temporal artery is rarely found. We report a case of 34 years old women, with facial AVF during her third pregnancy. The patient was admitted to the hospital with complain of pulsating headache, tinnitus, and pulsating mass on the left preauricular region. Arteriovenosus fistula diagnosis was confirmed by Digital Substraction Angiography (DSA), showing the left superficial temporal artery as the feeding artery. The headache and tinnitus was diminished immidiately after embolization procedure followed by ligation surgery.
\end{abstract}

Keywords: Arteriovenosus fistula, pregnancy, superficial temporal artery

\section{ABSTRAK}

Fistula arteriovenosus (FAV) pada arteri temporalis superfisialis (ATS) jarang ditemukan. Dilaporkan kasus seorang perempuan berusia 34 tahun yang mengalami FAV fasial dalam kehamilan anak ketiganya. Pasien mengeluhkan nyeri kepala berdenyut, tinnitus, dan massa berdenyut pada area preaurikularis kiri. Pemerikasan digital substraksi angiografi (DSA) mengkonfirmasi adanya FAV, dengan feeding artery berasal dari ATS kiri. Setelah tindakan embolisasi dan operasi penutupan fistula, keluhan nyeri kepala dan tinnitus menghilang.

Kata kunci: Arteri temporalis superfisialis, fistula arteriovenosus, kehamilan

*Bagian Ilmu Penyakit Saraf FK Universitas Udayana/RSUP Sanglah, Denpasar. Korespondensi: ilona.saputra@gmail.com.

\section{PENDAHULUAN}

Fistula arterivenosus (FAV) adalah suatu kondisi adanya hubungan langsung antara sistem arteri dan drainase vena, sehingga vena melebar, berkelok-kelok, dan muncul aneurisma pada segmen varicose, yang menyebabkan trombosis, ulserasi, dan ruptur. ${ }^{1}$ Berdasarkan predileksinya, FAV sering ditemukan pada daerah arteri intrakranial, jarang pada arteri temporal superfisialis (ATS), yaitu sekitar $0,5 \%$ hingga 2,0\% kasus. Mayoritas penyebabnya adalah trauma, baik trauma tumpul, tembus, maupun iatrogenik. $^{2}$

Fistula ini menghubungkan sistem arteri yang tekanan tinggi dengan sistem vena yang tekanan rendah dengan feeding artery berasal dari fasial temporal mengalir ke aliran vena tanpa melewati

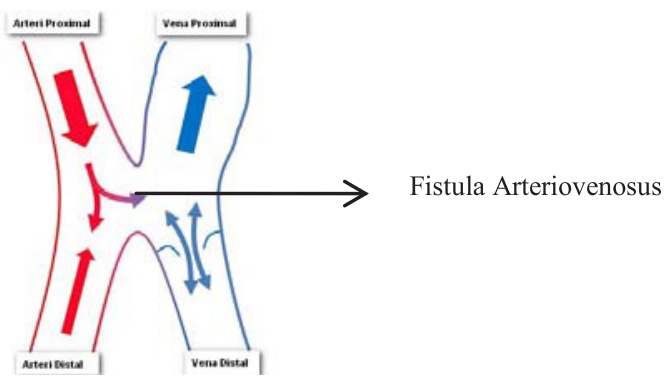

Gambar 1. Skema Aliran darah pada $\mathbf{F A V}^{4}$

Aliran darah dari arteri masuk ke sistem vena melalui suatu fistula, tanpa capilary bed. capilary bed (Gambar 1). Adanya FAV ini akan menyebabkan lesi pulsasi, bruit, tinitus, nyeri lokal, nyeri kepala, epilepsi, perdarahan, dan nekrosis pada daerah wajah. ${ }^{1,3}$

Aliran darah dari arteri masuk ke sistem vena melalui suatu fistula, tanpa capilary bed.

Penyebab FAV belum diketahui dengan pasti, namun sering dihubungkan dengan trombosis sinus dural dan vena. Peranan trombosis vena dengan hiperkoagubilitas seperti hiperhomosisteinemia, faktor V Leiden dan antitrombin, defisiensi protein $\mathrm{C}$ dan S, juga telah dilaporkan. Beberapa pasien dilaporkan memiliki riwayat operasi intrakranial, infeksi, paparan radiasi, hamil, atau trauma. ${ }^{5}$

Pada kehamilan terjadi proses fisiologis berupa perubahan hemostasis yang dapat memicu hiperkoagulasi dan terjadinya FAV. Namun hingga saat laporan ini ditulis, belum pernah dilaporkan adanya fistula arterivenosus ATS selama masa kehamilan.

\section{KASUS}

Perempuan berusia 34 tahun, mengeluhkan nyeri kepala progresif di sisi kiri selama 8 bulan yang bertambah berat sejak 1 minggu terakhir. Pasien diketahui sedang menjalani kehamilan aterm anak ketiga. Keluhan dirasakan seperti terikat di samping 


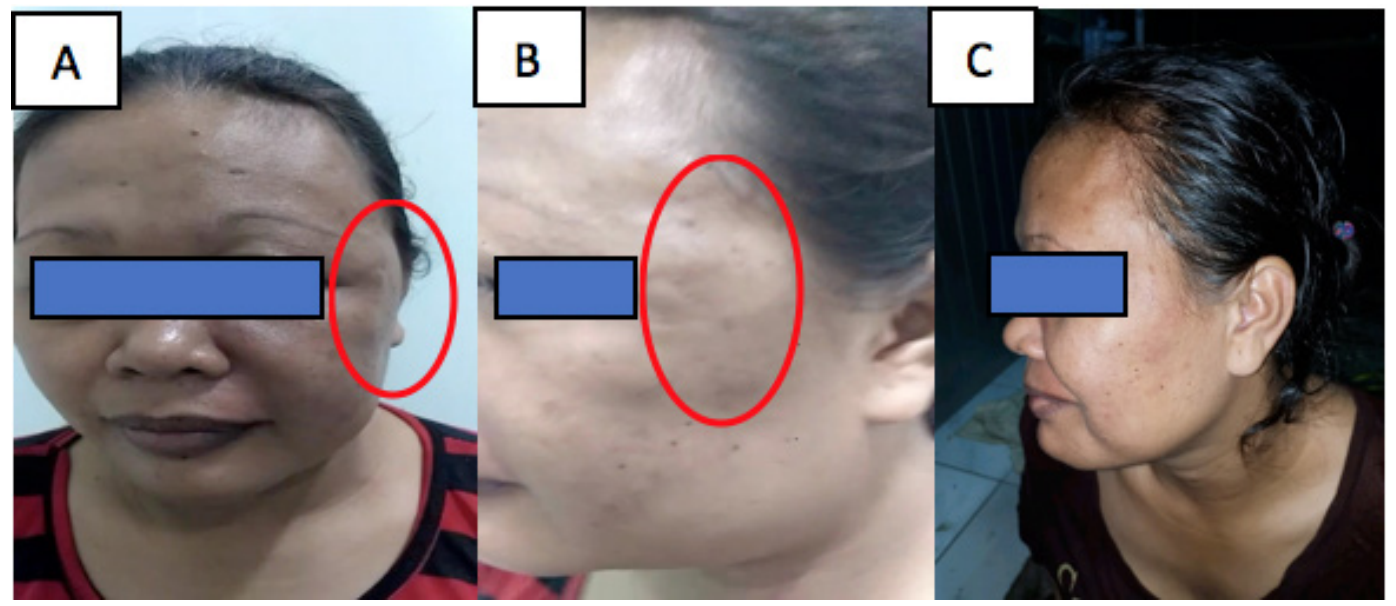

Gambar 2. Gambaran Klinis Pasien

A. Anterior; dan B. Lateral, pre-embolisasi, tampak massa bundar berdenyut di area preaurikular kiri; C. Pasca-embolisasi, tidak terlihat massa di area preaurikular kiri.

kepala dan berdenyut di telinga kiri yang menyebar sampai ke separuh wajah kiri, hilang timbul, dan memberat bila beraktivitas dengan kualitas nyeri 4/10. Selain itu, pasien juga mengalami gangguan tidur karena suara berdenging pada telinga kiri. Kehamilan dan persalinan sebelumnya berlangsung normal secara pervaginam.

Pada pemeriksaan fisik ditemukan masa berdenyut di pelipis kiri pasien berukuran $5 \times 6 \mathrm{~cm}$, terlihat seperti kumpulan pembuluh darah yang berkelok-kelok menyerupai cacing (Gambar 2A dan B). Ketika dilakukan penekanan pada bagian proksimal ATS, pulsasi menghilang. Auskultasi pada area temporal, rahang, dan leher kiri ditemukan

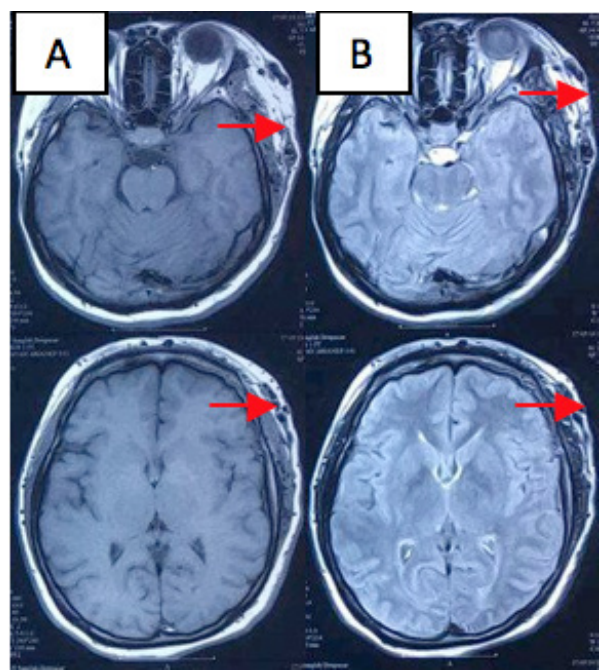

Gambar 3. MRI Potongan Aksial

A. T1 tanpa kontras dan B. T1-Flair; lesi dengan intensitas heterogen pada soft tissue regio temporoparietal kanan dengan gambaran flow void, dan ring worm apperance.
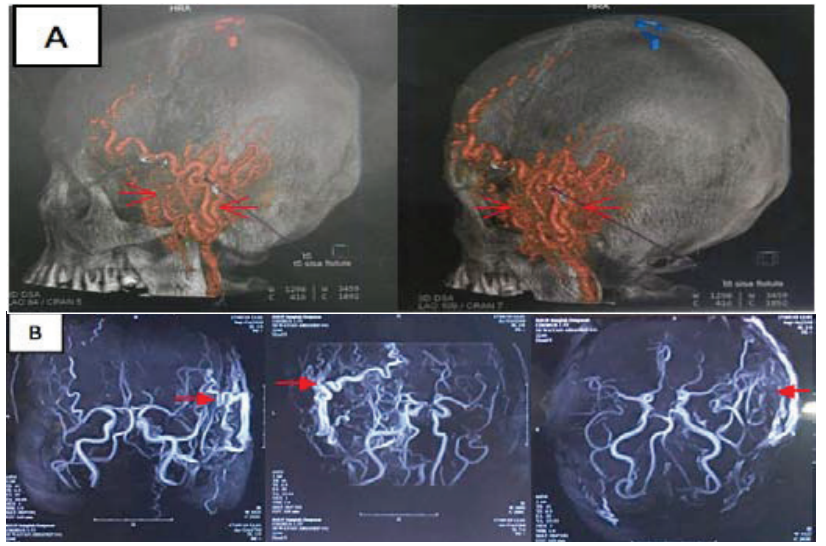

Gambar 4. A. 3-D MRA, dan B. MRA Menunjukkan Gambaran Lesi Malformasi Vaskular di Soft Tissue Temporoparietal Kanan

murmur dan bruit yang terdengar seperti hembusan angin. Tidak ada kelainan neurologis pada pasien tersebut.

Magnetic resonance imaging (MRI) memperlihatkan lesi dengan intensitas heterogen pada jaringan lunak regio temporoparietal kanan dengan gambaran flow void, dan ring worm apperance, tanpa kelainan intrakranial (Gambar 3). Adapun magnetic resonance angiography (MRA) menunjukkan gambaran lesi malformasi vaskular di jaringan lunak temporoparietal kanan, feeding artery dan draining vein sulit ditentukan (Gambar 4).

Dengan DSA terlihat adanya FAV pada ATS proksimal menuju vena-vena scalp dan ATS distal menuju vena fasial dengan dilatasi vena (Gambar 5). Pasien dilakukan embolisasi dan ligasi pada arteri temporalis superfisial proksimal dan distal. 


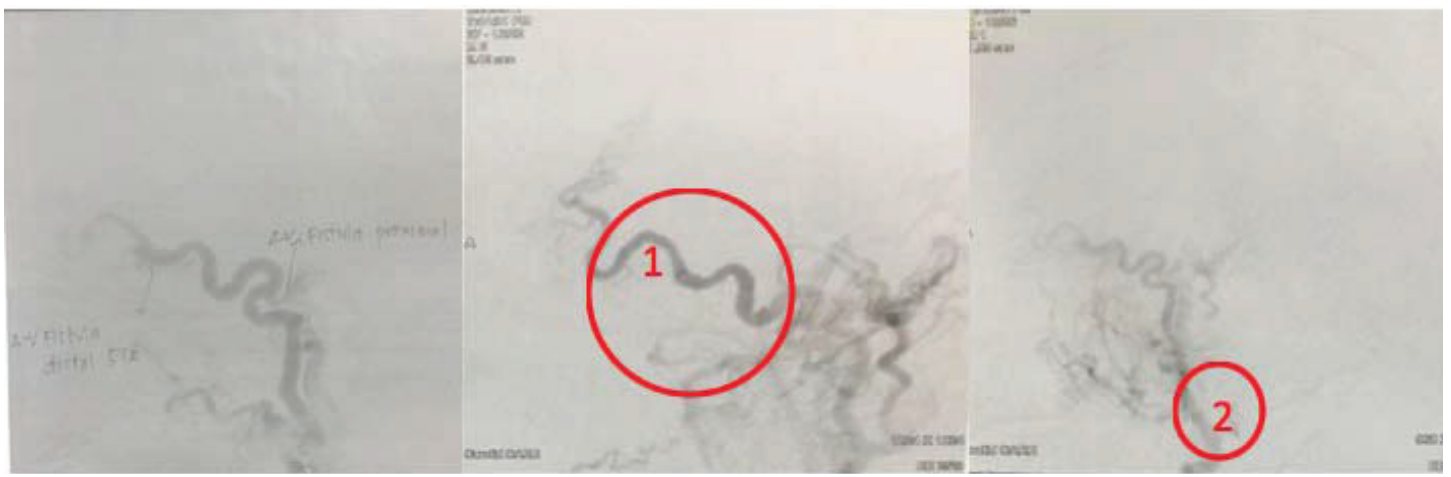

Gambar 5. DSA Memperlihatkan terdapat Dua Fistula

1. Arteri temporal superfisial proksimal menuju vena-vena scalp, 2. Arteri temporal superfisial distal menuju vena fasial dengan dilatasi vena.

Bruit menghilang setelah tindakan, tidak ditemukan komplikasi selanjutnya (Gambar 1C).

\section{PEMBAHASAN}

Pada ibu hamil, terjadi proses pertumbuhan pembuluh darah baru yang disebut angiogenesis. Hal ini terjadi jika pro-angiogenik melebihi anti-angiogenik. Hormon kehamilan (korionik gonadotropin, estradiol, dan progesteron) dapat membantu keseimbangan angiogenesis. Hipertrofi, elongasi, dan angiogenesis pembuluh darah selama kehamilan disebabkan penurunan resistensi vaskular di jaringan. Paparan estrogen terhadap endotel, enzim endothelial nitric oxide synthase (eNOS) dan cyclooxygenase (COX-1) meningkatkan vasodilatasi. Estrogen juga meningkatkan produksi vascular endothelial growth factor (VEGF), sehingga menyebabkan remodelling pembuluh darah. Angiogenesis arteri terutama terjadi pada tahap awal kehamilan, sebagai kompensasi aliran darah yang meningkat. Pada kehamilan trimester ke-3 terjadi peningkatan aliran darah yang menyebabkan vasodilatasi pembuluh darah. ${ }^{6}$ Perubahan fisiologis inilah yang mungkin menjelaskan FAV semakin bergejala dan membesar seiring dengan meningkatnya usia gestasi kehamilan pada pasien ini.

FAV yang terbentuk biasanya berlokasi pada area distribusi vena emisari yang menghubungkan sistem vena intrakranial dan ekstrakranial. Trombosis dapat menyebabkan inflamasi fokal pada tempat penetrasi vena emisari, sehingga terjadi ekspresi sitokin dan dilatasi pembuluh darah, dan terbukanya pirau arteri-vena fisiologis pada pembuluh darah kapiler. $^{7}$ Mayoritas (90\%) FAV pada daerah ini melibatkan ATS, dan pada $71 \%$ kasus, ATS bertindak sebagai feeder. ${ }^{8}$

Pada kasus ini, FAV terjadi pada pembuluh darah ekstrakranial dalam masa kehamilan yang belum pernah dilaporkan sebelumnya. Area preaurikular merupakan daerah paling sering terkena karena anatomi ATS dan vena temporalis superfisial (VTS) berjalan bersamaan pada tulang temporal. Arteri temporal superfisial berasal dari perbatasan kelenjar parotis dan melewati tengkorak dan kulit kepala, menuju temporal superior, dimana arteri ini rentan mengalami trauma dan menyebabkan FAV. ${ }^{9}$ Pada kasus ini tidak didapatkan riwayat trauma, melainkan FAV terjadi secara spontan dalam masa kehamilan anak ketiga. Lokasi FAV tersering yaitu pada ATS anterior dan posterior. Keluhan tinitus dapat terjadi karena FAV berada di sekitar telinga. ${ }^{10}$

Meskipun magnetic resonance dan $\mathrm{CT}$ scan sudah berkembang, angiografi tetap menjadi pemeriksaan diagnostik definitif untuk mengevaluasi FAV, karena dapat melihat resolusi spasial dan temporal. Angiografi juga dapat menggambarkan arteri yang memperdarahi dan aliran vena ke fistula dengan lebih akurat. Selanjutnya hasil angiografi menjadi dasar untuk menentukan tindakan yang akan dilakukan, baik endovaskular ataupun operasi. ${ }^{8}$

Ada beberapa pilihan metode terapi yang dapat digunakan untuk menangani kasus ini, yaitu operasi pengangkatan, ligasi feeding artery, embolisasi trans-arterial dan trans-vena, serta injeksi intralesi zat sklerosan. ${ }^{8,11}$ Endovaskular embolisasi merupakan manajemen penanganan primer FAV, yang bertujuan untuk mengobliterasi fistula antara feeding artery 
dan drainase vena. Pada kasus ini, pasien mengalami keberhasilan terapi embolisasi pada arteri temporalis superfisial proksimal dan distal, yang digabungkan dengan tindakan operasi ligasi pada arteri temporalis superfisial media. Embolisasi dilakukan dengan bahan embolan onyx dan coil. ${ }^{12-14}$ Jika FAV berada di luar sistem arteri karotid, yang memiliki sirkulasi kolateral kompleks yang potensial, mungkin sulit diobati. Selain itu, embolisasi yang tidak lengkap dapat menyebabkan kekambuhan. ${ }^{12,15}$

\section{KESIMPULAN}

Pada masa kehamilan, jika terdapat masa berkelok-kelok seperti cacing yang berpulsasi dan menghilang dengan penekanan ATS proksimal di wilayah temporal preaurikular, kemungkinan fistula arteriovenosus fasial perlu dipertimbangkan. Penatalaksanaan pengobatan dengan embolisasi yang dilanjutkan dengan operasi memberikan hasil yang baik tanpa adanya kekambuhan pada pemantauan satu tahun kemudian.

\section{DAFTAR PUSTAKA}

1. Mishra S, Panigrahi S, Parida D, Behera S. Usefulness of computed tomographic angiography in the management of extracranial scalp arteriovenous malformation. Neurol India. 2012;60(3):357-8.

2. Miekisiak G, Mis M, Sandler A, Druszcz A. Iatrogenic arteriovenousfistula of the superficial temporal artery. Oral Maxillofac Surg. 2008;12(4):219-21.

3. Moran AM, Aleman TS, Gausas RE, Fogt F. Traumatic arteriovenous fistula of the superficial temporal artery: a histopathologic report. Ophthalmic Plast Reconstr Surg. 2013;29(5):e126-8.

4. Sexton JA, Ricotta JJ. Endovascular approaches to arteriovenous fistula. Adv Surg. 2011;45:83-100.

5. Gupta AK, Periakaruppan AL. Intracranial dural arteriovenous fistulas: A Review. Indian J Radiol Imaging. 2009;19(1):43-48.
6. Boeldt DS, Bird IM. Vascular adaptation in pregnancy and endothelial dysfunction in preeclampsia. J Endocrinol. 2017;232(1):R27-44.

7. Ki HJ, Lee HK, Hur JW, Lee JW. Post-traumatic arteriovenous fistula of the scalp. J Korean Neurosurg Soc. 2015;58(3):298-300.

8. Zheng F, Pitts HA, Goldbrunner R, Krischek B. Case report traumatic arteriovenous fistula of the scalp in the left temporoparietal region with intra- and extracranial blood supply. Case Reports in Vasc Med. 2016;2016:1-4.

9. Yu J, Guo Y, Wu Z, Xu K. Traumatic arteriovenous fistula between the extracranial middle meningeal artery and the pterygoid plexus: case report and literature review. Interv Neuroradiol. 2017;23(1):906.

10. Asai K, Tani S, Imai Y, Mineharu Y, Sakai N. Traumatic arteriovenous fistula of the superficial temporal artery. J Surg Case Rep. 2015;1(3):12.

11. Janssen M, Vaninbroukx J, Fourneau I. Arteriovenous fistula after superficial temporal artery biopsy. Ann Vasc Surg. 2013;27(4):500-e1.

12. Samaniego EA, Fisher M, Hasan D, Guerrero WR, Fifi JT, Bottani L, dkk. Embolization of palpebral and orbito-frontal fistulas: technical and anatomical considerations in treating high-flow superficial skin lesions with liquid embolics. J NeuroIntervent Surg. 2017;10(3):240-5.

13. Santillan A, Nanaszko M, Burkhardt JK, Patsalides A, Gobin YP, Riina HA. Endovascular management of intracranial dural arteriovenous fistulas: a review. Clin Neurol Neurosurg 2013;115(3):241-51.

14. Naqvi J, Laitt R, Leatherbarrow B. Case of a spontaneous intraorbital arteriovenous fistula: clinicoradiological findings and treatment by transvenous embolisation via the superior ophthalmic vein. Orbit. 2013;32(2):124-6.

15. Dabus G, Pizzolato R, Lin E, Kreusch A, Linfante I. Endovascular treatment for traumatic scalp arteriovenous fistulas: results with Onyx embolization. J NeuroIntervent Surg. 2014;6(5):405-8. 